\title{
CHOREA CAUSED BY UNRUPTURED ARTERIOVENOUS MALFORMATION: CASE REPORT AND REVIEW OF LITERATURE
}

\author{
Pavao Jurinović, Eni Jadrijević, Ana Repić-Buličić and Marina Titlić
}

Clinical Department of Neurology, Split University Hospital Center, Split, Croatia

\begin{abstract}
SUMMARY - Chorea is a movement disorder that can be caused by a large range of degenerative, vascular, metabolic and toxic disorders in basal ganglia. Arteriovenous malformations are rare vascular malformations the clinical presentation of which depends on the malformation characteristics and localization. They are most commonly presented with intracranial hemorrhage, while focal neurological deficit is the rarest presentation. A case is reported of a 64-year-old female patient presented with hemichorea. Magnetic resonance imaging and digital subtraction angiography revealed the presence of arteriovenous malformation in the right temporal lobe.
\end{abstract}

Key words: Chorea; Movement disorders; Basal ganglia diseases; Arteriovenous malformations; Intracranial hemorrhages; Case reports

\section{Introduction}

Chorea is a movement disorder characterized by involuntary, purposeless, rapid movements of the limbs, trunk, neck and face. Chorea affecting one side of the body is called hemichorea. Different causes, including genetic, metabolic, pharmacological and structural, can lead to disturbances in basal ganglia, which leads to the loss of inhibition in subthalamic nucleus resulting in involuntary movements ${ }^{1-4}$. Huntington's disease, an autosomal dominant neurodegenerative disorder, is the best known cause of chorea. Chorea as a symptom may occur as part of Wilson's disease, benign hereditary chorea, neuroacanthocytosis, and some other inherited diseases ${ }^{3,5}$. Autoimmune disorders including systemic lupus erythematosus, Sjögren's syndrome and antiphospholipid syndrome may have chorea in their clinical presentation ${ }^{6-9}$. Sydenham's chorea occurs as a result of cross-reaction of antistreptococcal

Correspondence to: Eni Jadrijevic, $M D$, Clinical Department of Neurology, Split University Hospital Center, Spinčiceva 1, HR21000 Split, Croatia

E-mail: eni.jadrijevic@gmail.com

Received July 6, 2015, accepted October 6, 2015 antibodies with basal ganglia neurons ${ }^{10}$. While some causes of chorea may manifest as hemichorea, it is still more often a result of certain processes localized in contralateral basal ganglia. Hemichorea may occur in patients with nonketotic hyperglycemia, and can also be part of the paraneoplastic syndrome ${ }^{3}$.

Arteriovenous malformations (AVM) of the brain are rare vascular malformations that are supposed to be of congenital origin ${ }^{11}$. Their angioarchitecture is complex and includes arterial feeders, a net of dysplastic vessels, so-called nidus and draining veins ${ }^{12}$. Clinical presentation of AVM depends on hemodynamic characteristics and topography of the malformation ${ }^{13}$.

We report a case of a female patient with an AVM in the temporal lobe who presented with hemichorea.

\section{Case Report}

A 64-year-old female patient came with choreic movements that she had noticed one month before she was admitted to the hospital. In addition, she noticed handedness of the left arm and temporary episodes of numbness of the left arm and left side of the face. Occasionally, she observed tics of the left half of the face. 


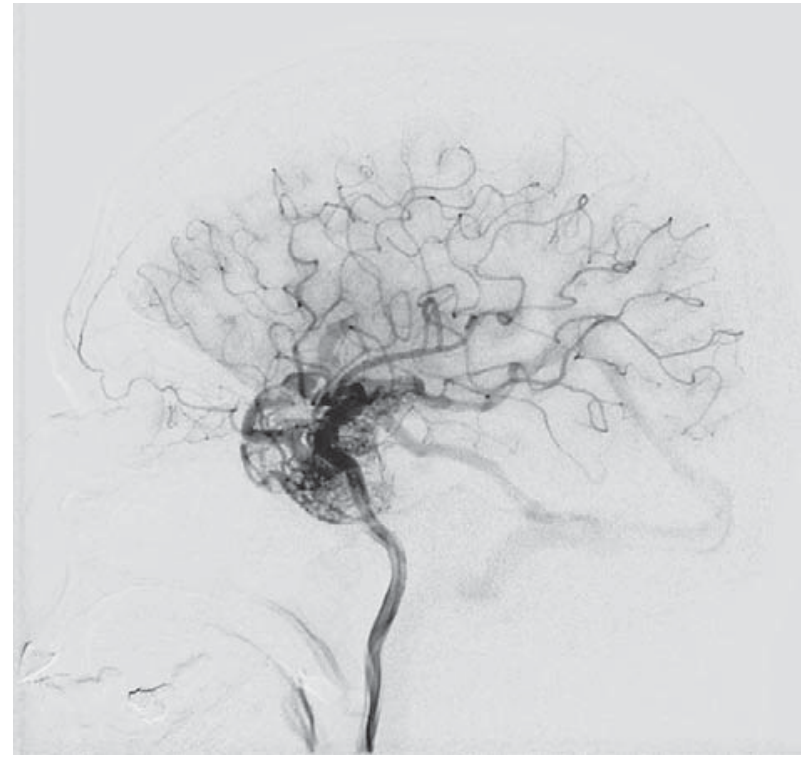

Fig. 1. Digital subtraction angiography shows plexiform arteriovenous malformation in the right temporal lobe.

In the past medical history, for more than thirty years she had asserted temporary occipital headaches accompanied with nausea and urge to vomit. Her neurological status was predominated by choreiform movements, along with discrete weakness of the left hand, atypical left plantar response, and dysmetria of the left hand. Tandem gait was poor. Laboratory tests showed elevated levels of cholesterol and triglycerides, while other parameters, including glucose, were within the reference values. Ultrasound examination of vertebral arteries showed mild stenosis of both internal carotid arteries. Multislice computed tomography of the brain did not show any acute focal lesions, while magnetic resonance imaging (MRI) of the brain revealed a pronounced tangle of punctiform tubular lesions of the flow void type, in the sense of tangle of small blood vessels, in the medial temporal lobe, the amygdala, and the right uncus. For objective evaluation of the described lesion, we performed digital subtraction angiography (DSA), which showed a plexiform arteriovenous malformation (AVM) in the right temporal lobe with numerous feeding arteries running from the lateral thalamostriatal perforators, as well as from both trunks of the insular segment of the right middle cerebral artery (M2) (Fig. 1). Over two wide, varicose drainage veins, malformation drained to Galen's vein and to the compound of the right transverse and sig- moid sinus. Angiography of the left vertebral artery showed a malformation probably situated just over the right posterior communicating artery. The patient was referred to treatment with embolization and 'gamma knife' method.

\section{Review of Literature}

The most common inherited cause of chorea is Huntington's disease, caused by abnormal expansion of CAG trinucleotide on chromosome 4p16. Although it usually occurs in middle age, Huntington's disease may occur in the seventh or eighth decade of life as a result of the small number of CAG trinucleotide repeats. In these cases, family history may be negative, either because of misdiagnosis, or because the carrier of the mutant gene had died before the onset of symptoms ${ }^{3,14}$. Vascular insult is the most common sporadic cause of chorea ${ }^{15}$. The incidence of chorea following stroke ranges from $0.5 \%$ to $1.3 \%{ }^{15,16}$.

Although movement disorders occur frequently in neurological practice, they are rarely the result of AVM. Lobo-Antunes et al. have described two patients with tremor and dystonia caused by AVM in the contralateral basal ganglia, thalamus and mesencephalon, one patient with torticollis and AVM in the posterior thalamus, and another one with retrocollis and AVM in the parietal lobe. In two patients, the presence of AVM was detected just after its rupture and subsequent subarachnoid hemorrhage. Selective embolization was performed in one patient with tremor, but without clinical improvement ${ }^{17}$. Krauss et al. report on six patients, of which one had hemidystonia caused by AVM in the contralateral frontoparietal lobe. Two patients had unilateral tremor associated with AVM in the contralateral frontal lobe. One patient developed hemidystonia and hemichorea-hemiballism after bleeding of temporo-occipital AVM, and two patients had focal hemidystonia caused by hemorrhage from AVM in the basal ganglia. Five patients were operated on and the movement disorder resolved in one of them ${ }^{18}$.

In the available literature, different movement disorders are reported as a result of AVM, either ruptured or not, while hemichorea is reported once as a result of ruptured AVM. In our case, hemichorea occurred as a result of unruptured AVM in the medial part of the temporal lobe, which makes this case unique. 


\section{Discussion}

Hemichorea can be caused by a large range of degenerative, vascular, metabolic and toxic disturbances in the contralateral basal ganglia ${ }^{19,20}$. Among these, acute vascular incident is the most common cause ${ }^{21}$. The pathophysiological mechanism leading to hemichorea is complex and not yet completely understood. According to the widely accepted hypothesis, hyperkinetic movement disorders occur due to the loss of subthalamic nucleus control on the internal segment of the globus pallidus (GPi), which leads to disinhibition of the thalamus. Furthermore, decreased striatal inhibitory activity on the external part of the globus pallidus $(\mathrm{GPe})$ results in increased inhibitory activity of the GPe, which in turn results in overinhibition of the subthalamic nucleus leading to hypoactivity of the GPi. This decreased inhibitory activity from basal ganglia neurons leads to unrestrained thalamocortical drive and the appearance of dyskinesias ${ }^{22-24}$.

Arteriovenous malformations most commonly present with intracranial hemorrhage, epilepsy, headache, or focal neurologic deficits ${ }^{25}$. Intracranial hemorrhage is the most common clinical presentation of $\operatorname{AVM}(53 \%)^{26}$. Annual risk of hemorrhage is estimated to $2 \%-4 \%$, and the risk of re-rupture is increased to up to $18 \%$ in the first year after initial bleeding ${ }^{27,28}$. Epilepsy is the first clinical manifestation of AVM in $16 \%-53 \%$ of cases $^{29}$. In the majority of these cases, seizures are focal, while generalized seizures occur in 30\% of cases ${ }^{30}$. Chronic headache occurs in 7\%-48\% of patients with $\mathrm{AVM}^{29}$. According to a survey conducted in 1999 by the Arteriovenous Malformation Study Group, no headache characteristics such as frequency, duration and severity can indicate the presence of $\mathrm{AVM}^{31}$. Focal neurologic deficit is the rarest clinical presentation of AVM. According to a study that included 1289 patients with brain AVM, reversible focal neurologic deficits were present in 8\%, persistent neurologic deficits in 7\%, and progressive neurologic deficits in $5 \%$ of patients ${ }^{26}$.

Although AVM is assumed to be of congenital origin, most of them are clinically presented later in life. The mean age at clinical presentation is in the third or fourth decade of life, with equal sex distribution ${ }^{13,32}$. AVM may become symptomatic by several different mechanisms. The first one is hemorrhage, which may be subarachnoid, intraventricular, or in the brain pa- renchyma. Secondly, the size of AVM may be such as to exert pressure upon certain parts of the brain (mass effect). Finally, a large volume of blood shunted through the AVM may result in so-called 'steal phenomenon' that leads to temporary or permanent ischemia of neuronal structures ${ }^{17,18,32}$. The concept of 'steal phenomenon' has been recently challenged ${ }^{29}$. A1though most AVM are diagnosed after the onset of acute hemorrhage, epilepsy or focal neurologic deficit, a growing number of AVM are found accidentally on imaging investigations prescribed for other reasons ${ }^{26,33}$. Computed tomography and MRI are used in diagnosing AVM, but definitive diagnosis is based on DSA, which provides most information on the angioarchitecture and hemodynamics malformations.

Certain characteristics of AVM are associated with an increased risk of hemorrhage, i.e. deep venous drainage, presence of aneurysm in the nidus or in the arterial feeder, and deep localization of $\mathrm{AVM}^{25,34}$. Other studies found no positive correlation of these factors with an increased risk of hemorrhage $e^{35}$, but most studies showed the risk of hemorrhage to increase with age, growing by about one-third with all decades of life $\mathrm{f}^{34,35}$.

Arteriovenous malformations are classified according to Spetzler-Martin's classification in six grades. This classification considers the size of the malformation, the proximity of the functional centers in the brain, so-called eloquent areas of the brain, and the type of venous drainage ${ }^{36}$. Also, this classification is widely used for the choice of therapy and to predict the outcome of certain therapeutic procedures. Grade VI represents inoperable $\mathrm{AVM}^{36}$. Considering therapeutic outcomes of certain grades of AVM, in 2011 Spetzler and Ponce reclassified Spetzler-Martin classification into three groups: low surgical risk for grades I and II, intermediate surgical risk for grade III, and high risk for grades IV and $\mathrm{V}^{37}$.

There are several treatment options for AVM, i.e. neurosurgical operations, stereotactic radiotherapy, and endovascular embolization ${ }^{38}$. Today, surgical management is recommended for grades $\mathrm{I}$ and $\mathrm{II}^{39}$, multimodality treatment for grade III, and observation is usually recommended for grades IV and V, except for patients with recurrent hemorrhage, progressive neurologic deficit, or medically intractable seizures caused by the $\mathrm{AVM}^{40}$. In patients with contraindications for surgery, stereotactic radiotherapy may be an effective way of treatment of $\mathrm{AVM}^{41}$. Unlike the immediate ef- 
ficacy of surgery, the results of stereotactic radiotherapy evolve over several years, during which the risk of hemorrhage persists, and the risk of adverse effects of radiation on the surrounding tissue should also be assessed. Endovascular embolization is most commonly used as adjunctive therapy in the treatment of AVM, mainly to facilitate or make surgery or radiotherapy safer. To achieve desirable outcome of treatment of AVM, it is necessary to estimate the risk of an event due to the natural course of the disease against the risk of a particular therapeutic option ${ }^{38}$.

The case presented shows that a relatively common symptomatology such as movement disorder in the background may have a rare cause such as AVM. Careful medical history and examination with neuroradiological imaging are the key to successful diagnosis. In such cases, an interdisciplinary team of neurologists, neurosurgeons and neuroradiologists is required to make the best decision on the therapeutic choice that will have a favorable outcome for the patient.

\section{References}

1. Mosby's Medical Dictionary, $8^{\text {th }}$ edition. St. Louis, MO: Elsevier; 2009.

2. The American Heritage Medical Dictionary. Boston: Houghton Mifflin Company; 2007.

3. Walker RH. Differential diagnosis of chorea. Curr Neurol Neurosci Rep. 2011 Aug;11(4):385-95. doi: 10.1007/s11910-011-0202-2.

4. Berman SA. Chorea. In: Joseph AB, Young RR, eds. Movement Disorders in Neurology and Neuropsychiatry, $2^{\text {nd }}$ ed. Malden, Mass: Blackwell Science;1999; p. 481-94.

5. Machado A, Chien HF, Deguti MM, Cançado E, Azevedo RS, Scaff M, et al. Neurological manifestations in Wilson's disease: report of 119 cases. Mov Disord. 2006;21:2192-6. doi: $10.1002 /$ mds. 21170

6. Font J, Cervera R, Espinosa G, Pallarés L, Ramos-Casals M, Jiménez S, et al. Systemic lupus erythematosus (SLE) in childhood: analysis of clinical and immunological findings in 34 patients and comparison with SLE characteristics in adults. Ann Rheum Dis. 1998;57:456-9.

7. Watanabe T, Onda H. Hemichorea with antiphospholipid antibodies in a patient with lupus nephritis. Pediatr Nephrol. 2004;19:451-3. doi:10.1007/s00467-003-1388-6

8. Venegas FP, Sinning M, Miranda M. Primary Sjögren's syndrome presenting as a generalized chorea. Parkinsonism Relat Disord. 2005;11:193-4. doi:10.1016/j.parkreldis.2004.10.006

9. Ciubotaru CR, Esfahani F, Benedict RH, Wild LM, Baer AN. Chorea and rapidly progressive subcortical dementia in antiphospholipid syndrome. J Clin Rheumatol. 2002;8:332-9.
10. Kirvan CA, Swedo SE, Heuser JS, Cunninghman MW. Mimicry and autoantibody-mediated neuronal cell signaling in Sydenham chorea. Nat Med. 2003;9:914-20.

doi: $10.1038 / \mathrm{nm} 892$

11. Stapf C, Mast H, Sciacca RR, Berenstein A, Nelson PK, Gobin YP, et al. The New York Islands AVM study: design, study progress, and initial results. Stroke. 2003;34:e29-33.

doi: 10.1161/01.STR.0000068784.36838.19

12. Forsting $M($ ed). Intracranial Vascular Malformations and Aneurysms. Berlin/Heidelberg: Springer-Verlag, 2006; p. 101-42.

13. De Blasi R, Salvati A, Medicamento N, Chiumarulo L. Clinical features and classification of brain AVMs and cranial DAVFs. Neuroradiol J. 2009 Dec 14;22(5):568-80. doi: 10.1177/197140090902200510

14. Warren JD, Firgaira F, Thompson EM, Kneebone CS, Blumbergs PC, Thompson PD. The causes of sporadic and 'senile' chorea. Aust N Z J Med. 1998;28:429-31.

15. Alarcón F, Zijlmans JCM, Duenas G, Cevallos N. Post-stroke movement disorders: report of 56 patients. J Neurol Neurosurg Psychiatry. 2004;75:1568-74.

doi: 10.1016/j.parkreldis.2005.08.009

16. Chung SJ, Im JH, Lee MC, Kim JS. Hemichorea after stroke: clinical-radiological correlation. J Neurol. 2004;251:725-9. doi: 10.1007/s00415-004-0412-5

17. Lobo-Antunes J, Yahr MD, Hilal SK. Extrapyramidal dysfunction with cerebral arteriovenous malformations. J Neurol Neurosurg Psychiatry 1974 Mar;37(3):259-68.

18. Krauss JK, Kiriyanthan GD, Borremans JJ. Cerebral arteriovenous malformations and movement disorders. Clin Neurol Neurosurg. 1999;101(2):92-9.

19. Kasse CS, Maulsby GO, de Juan E, Mohr JP. Hemichoreahemiballism and lacunar infarction in the basal ganglia. Neurology. 1981;31:452-5.

20. Shan DE, Ho DMT, Chang C, Pan H-C, Teng MMH. Hemichorea-hemiballism: an exploration for MR signal changes. Am J Neuroradiol. 1998;19:863-70.

21. Dewey RB, Jankovic J. Hemiballism-hemichorea: clinical and pharmacological findings in 21 patients. Arch Neurol. 1989; 46:862-7.

22. DeLong MR. Primate models of movement disorders of basal ganglia origin. Trends Neurosci. 1990;40:281-5.

23. Albin RL, Young AB, Penney JB. The functional anatomy of basal ganglia disorders. Trends Neurosci. 1989;12:366-75.

24. Crossman AR. Primate models of dyskinesia: the experimental approach to the study of basal ganglia-related involuntary movement disorders. Neuroscience. 1987;21:1-40.

25. Al-Shahi R, Warlow C. A systematic review of the frequency and prognosis of arteriovenous malformations of the brain in adults. Brain. 2001;124:1900-26.

26. Hofmeister C, Stapf C, Hartmann A, Sciacca RR, Mansmann $\mathrm{U}$, terBrugge $\mathrm{K}$, et al. Demographic, morphological, and clinical 
characteristics of 1289 patients with brain arteriovenous malformation. Stroke. 2000 Jun;31(6):1307-10.

27. Ondra SL, Troupp H, George ED, Schwab K. The natural history of symptomatic arteriovenous malformations of the brain: a 24-year follow-up assessment. J Neurosurg. 1990;73:387-91. doi:10.3171/jns.1990.73.3.0387

28. Halim AX, Johnston SC, Singh V, McCulloch CE, Bennett JP, Achrol AS, et al. Longitudinal risk of intracranial hemorrhage in patients with arteriovenous malformation of the brain within a defined population. Stroke. 2004;35:1697-702. doi: 10.1161/01.str.0000130988.44824.29

29. Mast H, Mohr JP, Osipov A, Pile-Spellman J, Marshall RS, et al. "Steal" is an unestablished mechanism for the clinical presentation of cerebral arteriovenous malformations. Stroke. 1995;26:1215-20.

30. Osipov A, Koennecke HC, Hartmann A, Young WL, PileSpellman J, Hacein-Bey L, et al. Intervent Neuroradiol. 1997;3:37-41.

31. The Arteriovenous Malformation Study Group. Arteriovenous malformations of the brain in adults. N Engl J Med. 1999;340:1812-8. doi:10.1056/NEJM199906103402307.

32. Laakso A, Dashti R, Juvela S, Niemelä M, Hernesniemi J. Natural history of arteriovenous malformations: presentation, risk of hemorrhage and mortality. Acta Neurochir Suppl. 2010; 107:65-9. doi: 10.1007/978-3-211-99373-6_10.

33. Morris Z, Whiteley WN, Longstreth WT Jr, Weber F, Lee YC, Tsushima Y, et al. Incidental findings on brain magnetic resonance imaging: systematic review and meta-analysis. BMJ. 2009;339:b3016. doi: 10.1136/bmj.b3016.
34. Gross BA, Du R. Natural history of cerebral arteriovenous malformations: a meta-analysis. J Neurosurg. 2013;118:437-43. doi: 10.3171/2012.10.JNS121280.

35. Kim H, Al-Shahi Salman R, McCulloch CE, Stapf C, Young WL: MARS Coinvestigators. Untreated brain arteriovenous malformation: patient-level meta-analysis of hemorrhage predictors. Neurology. 2014;83:590-7. doi: 10.1212/WNL.0000000000000688.

36. Spetzler RF, Martin NA. A proposed grading system for arteriovenous malformations. J Neurosurg.1986;65:476-83. doi: 10.3171/jns.1986.65.4.0476

37. Spetzler RF, Ponce FA. A 3-tier classification of cerebral arteriovenous malformations. (Clinical article). J Neurosurg. 2011;114:842-9. doi:10.3171/2010.8.JNS10663

38. Conger A, Kulwin C, Lawton MT, Cohen-Gadol AA. Diagnosis and evaluation of intracranial arteriovenous malformations. Surg Neurol Int. 2015;6:76. doi: 10.4103/2152-7806.156866

39. Morgan MK, Rochford AM, Tsahtsarlis A, Little N, Faulder KC. Surgical risks associated with the management of grade I and II brain arteriovenous malformations. Neurosurgery. 2004;54:832-7.

40. Han PP, Ponce FA, Spetzler RF. Intention-to-treat analysis of Spetzler-Martin grades IV and V arteriovenous malformations: natural history and treatment paradigm. J Neurosurg. 2003;98:3-7. doi: 10.3171/jns.2003.98.1.0003

41. Starke RM, Yen CP, Ding D, Sheehan JP. A practical grading scale for predicting outcome after radiosurgery for arteriovenous malformations: analysis of 1012 treated patients. J Neurosurg. 2013;119:981-7. doi: 10.3171/2013.5.JNS1311.

Sažetak

\title{
KOREA UZROKOVANA ARTERIOVENSKOM MALFORMACIJOM: PRIKAZ SLUČAJA I PREGLED LITERATURE
}

\author{
P. Jurinović, E. Jadrijević, A. Repić-Buličić i M. Titlić
}

Korea je poremećaj pokreta koji može biti uzrokovan velikim rasponom degenerativnih, vaskularnih, metaboličkih i toksičnih poremećaja u bazalnim ganglijima. Arteriovenske malformacije su rijetke vaskularne malformacije klinička prezentacija kojih ovisi o karakteristikama i lokalizaciji malformacije. Najčešće se prezentiraju intrakranijskom hemoragijom, a najrjeđe fokalnim neurološkim deficitom. Prikazujemo slučaj 64-godišnje bolesnice koja se prezentirala hemikoreom. Učinjena magnetska rezonanca i digitalna subtrakcijska angiografija otkrila je prisutnost arteriovenske malformacije u medijalnom dijelu desnog temporalnog režnja.

Ključne riječi: Korea; Pokretljivost, poremećaji; Bazalni gangliji, bolesti; Arteriovenske malformacije; Intrakranijska krvarenja; Prikazi slučaja 